\title{
Helping Students to Write Better through Reading and Writing Connections Strategy
}

Erlina*, Rita Hayati, Hariswan Putra Jaya

Faculty of Teacher Training and Education, Sriwijaya University, Jalan Raya Palembang Prabumulih Ogan Ilir South Sumatera, Indonesia

Corresponding Author: Erlina, E-mail: erlinahamid@yahoo.com

\section{ARTICLE INFO}

Article history

Received: April 16, 2018

Accepted: July 21, 2018

Published: November 01, 2018

Volume: 7 Issue: 6

Advance access: September 2018

Conflicts of interest: None

Funding: Sriwijaya University

\begin{abstract}
One of the causes of students' difficulties in writing is related to the lack of knowledge on how to write. This might be caused by the lack of awareness that a piece of writing might have its own pattern or organization of ideas depending on the topic. Therefore, students need to be exposed with different kinds readings materials in order to develop their awareness on how writing is developed into differrent kinds of patterns of ideas. This study is intended to help students improve their writing achievement especially in writing an essay by integrating the reading and writing activitivities. The students involved in an integrated reading and writing activity in order to help the students develop their writing skills. This study involved 16 students of English Education Study Program who took the writing 3 course. Therefore, convinient sampling method is applied. The results of this study showed that there was an improvement in the students' writing achievement in means from 63.3 in pretest to 79.8 in the post test. The results of the paired-sample t-test also confirmed that there is a significant difference in students' essay writing achievement before and after they were taught by using reading and writing connections strategy. Organization of ideas, focus and detail, and voice are the aspects which were mostly developed after the treatment. Therefore, it can be concluded that reading and writing connections strategy is effective in improving students' essay writing achievement.
\end{abstract}

Key words: Essay Writing, Reading and Writing Connections Strategy

\section{INTRODUCTION}

The ability to write is one of the indicators of one's success in learning a language including in learning English as a foreign language. With the development of science and technology, written media has become one of the means of communication that is very effective in conveying ideas to the public either through print or electronic media. In the academic world, writing ability is even one of the indicators of academic professionalism as academics are expected to publish their scientific works in reputable journals. In other words, with good writing skills one has a better chance to communicate his or her ideas to the more wider audience and develop his or her expertise in certain areas.

Unfortunately, writing is the most difficult language skills for most language learners, including for those who learn English as a foreign language. Unlike speaking, writing is considered the most difficult skill because the reader will not tolerate any mistakes generated by the author on the results of his writing because the error will be immediately visible and will disturb the meaning process made by the reader. Writing therefore requires mastery of some skills that will help the writer produce good writing, such as the ability to develop ideas, grammatical comprehension, and vocabulary mastery. Lack of ability to master these skills can lead to lack of ability to produce good writing.

The same thing is experienced by most students of English Education Study Program of Faculty of Teacher Training and Education (FKIP) of Sriwijaya University (Unsri). The results of an interview with the students who took writing 3 course showed that most students still have difficulties in writing an essay. The difficulties they encounter are lack of ability to develop ideas, use good grammar and correctness, use appropriate vocabulary, and organize ideas into good writing. This lead to the students' low achievement in writing. Therefore, efforts need to be done to improve the students' ability in writing, especially in writing an essay.

According to Oshima and Hogue (1999, p 100), an essay is a writing that consists of several fairly long paragraphs that deal with a particular topic. But the topic to be discussed is too complex if only elaborated in a single paragraph, so the translation of the topic needs to be broken down into several paragraphs. In other words, essay writing has a higher writing complexity than writing a paragraph because the writer should be able to spell ideas from one topic into several unified paragraphs. Due to the high complexity of writing an essay, appropriate learning strategies are needed so that students can further improve their ability to write an essay. 
One of the strategies in teaching writing is through the use of reading and writing connections. Various studies have shown that there is a very close relationship between reading and writing activities. Research conducted by Corden (2007) indicates that reading, discussing, and evaluating the text of mentors can have a positive impact on the quality of writing of an independent child. Furthermore, Shen (2009) found that reading helped develop the ability of English Language Learning as a foreign language through stimulus, structure, vocabulary, and previous experience (Schema). Furthermore, the results of a study done by Shim (2004) indicates that the constructed model of the data shows that the planning and impacts have a great effect on draft writing and draft writing and their impact is an important factor in revision. This is based on the assumption that the reading process represented by all these factors is the same as the writing process. It can be concluded that there is a close relationship between reading and writing activities that contribute to the development of writing skills.

What and how does the actual contribution of reading activities to the development of writing skills are explained as follow. Tompkins (2008) says that at the time of reading, one can not only read to search for information contained in the reading but the reader can also recognize the structure of the writing and understand how the author develops an idea into a story or writing. An understanding of how a writer writes will be able to help someone to write well. It implied that reading should be done on purpose and students should be exposed with the reading activities before they write in order to help them get some ideas on how a topic should be developed and organize the ideas based on some specific pattern of writing. Therefore, reading and writing connections is a good way to help students to write better.

Tompkins (2008) states that the teaching of writing should be done integratedly with the reading activities. It implies that students should be involved in teaching and learning activities which integrate these two activities as it will provide opportunities for the students to write better. Furthermore, Tomkins (2008) states that doing exploration activities is one of the ways. Exploration activities are activities in which the reader investigates how an author uses storylines, characters, settings, themes, and points of view. In other words, exploratory activities help students to understand the mind of an author by building their understanding of how the process of writing a story and what things should be developed or noticed. Exploration activities are conducted by integrating several activities such as reading, listening, discussing, reviewing, visualizing, and writing. Basically, this exploration activity is based on two main activities, namely reading and writing. Reading and writing activities are important because at the time of reading, the reader will learn how the author uses certain structures and understand the impact (Tompkins, 2008). This means, in reading-writing activities, the reading process does not only focus on information seeking activities but also related to the process of identifying the structure of writing and the identification of the process of developing ideas or ideas conducted by a writer in a writing. Thus, it is expected that readers can understand the structure of writing a scientific work and observe how an idea is developed by the author. In other words, by exploring the reading materials, it is expected that the reader can identify the process of how an author develop the ideas in writing a scientific work so that he or she can implement it on his or her own writing process (Tompkins, 2008).

Based on the problems above, this study focuses on the use of reading and writing connections strategy in the teach-ing of writing to the fifth semester students of English and Education Study Program of Faculty of Teacher Training and Education of Sriwijaya University. The aims of this study was to find some information on whether there is significant difference in essay writing achievement of the fifth semester students of English education study program of FKIP Unsri between before and after they are taught using reading and writing connections strategy as well as to find out which as-pects of writing which mostly improved after having taught through reading and writing connection strategy.

\section{LITERATURE REVIEW}

\section{Essay Writing}

An essay is a writing consisting of several paragraphs with the same topic (Oshima and Hogue, 1999). The essay consists of three parts: opening, content, and closing paragraph. The opening paragraph consists of two parts: some general statement on the subject that can attract the reader's attention and the thesis statement containing the sub topic to be discussed. Thesis statement serves as a topic sentence on an essay. The content of a paragraph consists of one or more paragraphs. Each paragraph develops each sub topic in the thesis statement so that the number of paragraphs of the contents depends on the number of sub topics to be discussed. The closing paragraph is the same as the closing sentence in a paragraph. This paragraph serves to conclude the content or main points that have been discussed previously.

\section{Reading Writing Connections Strategy}

The results of research and expert opinion support the statement that combining reading and writing activities can improve literacy skills. According to Bromley (1989, p.122), there are three reasons why the teaching of reading should be related to the learning of writing: (1) the ability to read and write develop simultaneously, (2) the reading and writing skills reinforce each other, and (3)) through reading and writing, language is used as a communication tool. Children naturally learn to speak and hear, and literacy activities that combine reading and writing can broaden the language used everyday into a form of writing. In other words, the merging of reading and writing activities makes one's literacy experience perfect because of the natural balance between the input and the output of the language (Bromley, 1989).

One activity that can be used to make reading and writing activities simultaneously is through text exploration activities. Text exploration activities are widely used in learning to write stories, especially narrative texts. In story exploration activities, the reader investigates how the author uses plots, characters, settings, themes, and point of view. Some 
activities such as retelling and demonstrating the contents of the story, comparing stories with different versions, and writing the latest version of a story will give readers the opportunity to consolidate their understanding of the content as well as gain experience on how to write a story well (Tompkins, 2008). Here are 10 activities done on text exploration activities that integrate reading and writing activities:

- class collaboration retelling of stories

- $\quad$ retelling and telling stories

- $\quad$ retelling stories with pictures

- retelling stories in writing

- dramatizing stories

- drawing story diagrams

- comparing versions of stories

- creating open-mind portraits

- writing dialogue

- $\quad$ Retelling stories from different points of view

In this research, text exploration activities will be implemented on different text types, that is an essay. Essays have characteristics and structure of text that is different from the narrative text so that exploration activities should be tailored to the characteristics of the essay. Reading writing connections on the essay text will be simpler and include only a few activities as follows:

- $\quad$ Reading the text

- Analyze the text in terms of its structure, organization of ideas, and language features

- Writing the outline of the text

- Rewriting the text with your own words.

- Final Outcome: write an essay based on a topic given (Adapted from Tompkins, 2008)

With this text exploration activities, students are expected to read the sample essay, analyze it in terms of the content, the structure of the text, and the organization of ideas of the text. By doing this critical reading activities, it is expected that the students can build their understanding on how an author develop an idea into a piece of writing. Thus, it will help them to write their own essay.

\section{RESEARCH METHODS}

\section{Method}

The method to be used in this research is experimental method using one group pretest post test design. In this research, the writer did an experiment on the use of reading and writing connections strategy in improving the students' writing achievement in writing an essay. In this study, students were given the treatment of reading and writing connection strategy in 14 meetings. They involved in activities of reading some good sample essays, analyze the structure of the text, choice of words, and the organization of the ideas. After that students were asked to write the outline of the essay and write it again into an essay with their own words.

\section{Samples of the Study}

The sample of this study was the fifth semester students of English Education Study Program of FKIP Unsri who took the writing III course. There were 16 students involved in this study.

\section{Technique for Collecting the Data}

In collecting the data, some instruments were used as follows:

\section{Writing test}

The writing test was conducted at the beginning and end of the study to determine the progress experienced by the student before and after treatment by using the reading and writing connections strategy. At the end of the study, students were asked to write an essay. The results of the students' writing were scored by two raters using an essay scoring rubric of five scientific criteria, namely focus and details, organization, voice, word choice, and sentence structure, grammar, mechanics, and spelling (wid.ndia.org).

\section{Technique for analyzing the data}

Paired sample t-test was applied to find out whether there is a significant difference in essay writing achievement of the fifth semester students of English Education Study Program of FKIP Unsri between before and after they are taught writing through the use of reading and writing connection strategy.

\section{RESULTS}

\section{Results of students' writing pretest and postest}

Students' essay writing both for pretest and posttest were scored by two raters based on the rubric provided. The scores from both raters were checked its reliability by using intraclass correlation coefficient analysis. The result of statistical analysis showed that the reliability coefficient of the pretest scores from rater 1 and 2 was 0.924 . This means that the scores of rater 1 and 2 have high reliability because the minimum value is 0.70 . In other words, rater 1 and rater 2 have similar perceptions of students' inital ability in writing an essay. The reliability check for the post test results showed that the reliability coefficient of rater 1 and 2 has a cronbach alpha value of 0.83 . This means that the score of rater 1 and 2 have high reliability because the minimum value is 0.70 . In other words, rater 1 and rater 2 have similar perceptions on students' essay writing ability for the post test results.

Based on the findings, in the pretest there were 4 (25\%) students have grades in the range of $41-55$ or are in the poor category, $6(37.5 \%)$ are in the range of 56-70 or are in fair category, and $6(37.5 \%)$ students are in range of $71-85$ or are in good category. In other words, the pretest results showed, the students' achievement in writing an essay is still very low' the lowest score was 47.5; the highest score was 72.5; and the average score was 63.3 or are in fair category. The results were described in Table 1 below.

Based on the findings of the post test, it was found that the students' essay writing achievement increased from the average of 63.3 to 79.8 or increased from the fair to good 
category. In detail, it can be described that $(25 \%)$ students have writing skill in very good category, $8(50 \%)$ students have writing skill in good category, and $4(25 \%)$ students are in fair category. Thus, no more students were in the poor category. The results were described in Table 2 below.

The result of the normality test for pretest and post test showed that both pretest and post test results of students'

Table 1. The results of students' pretest in essay writing

\begin{tabular}{lcc}
\hline Category & Total & Percentage \\
\hline $\begin{array}{l}\text { Very good } \\
(86-100)\end{array}$ & 0 & 0 \\
$\begin{array}{l}\text { Good } \\
(71-85)\end{array}$ & 6 & 37.5 \\
$\begin{array}{l}\text { Fair } \\
(56-70)\end{array}$ & 6 & 37.5 \\
$\begin{array}{l}\text { Poor } \\
(41-55)\end{array}$ & 4 & 25 \\
Fail & & \\
$(0-40)$ & 0 & 0 \\
Total & & \\
\hline
\end{tabular}

Table 2. The results of students' post test in essay writing

\begin{tabular}{lcc}
\hline Category & Total & Percentage \\
\hline $\begin{array}{l}\text { Very good } \\
(86-100)\end{array}$ & 4 & 25 \\
$\begin{array}{l}\text { Good } \\
(71-85)\end{array}$ & 8 & 50 \\
Fair & & \\
$(56-70)$ & 4 & 25 \\
Poor & & \\
$(41-55)$ & 0 & 0 \\
Fail & & \\
$(0-40)$ & 0 & 0 \\
Total & 16 & 100 \\
\hline
\end{tabular}

essay writing were normal. The result of Shapiro Wilk test showed that the p-value of the pretest test was 0.846 and the p-value of the post test test was 0.946. Since p-value of the pretest and post tests was greater than 0.05 , the pretest and post test results were considered normal.

The paired-sample t-test was then performed to determine whether there is a significant difference between the pretest and post test results. The results showed in Table 3 that the t obtained value is -7.361 . Since the $t$ value is smaller than 0.05 , it can be concluded that there is a significant difference in students' essay writing achievement between before and after they have been taught through reading and writing connections strategy.

\section{Results in aspects of students'writing}

Students' writing were assessed based on the aspects of writing. The results of pretest and posttest also showed an improvement in the aspects of the students' writing as described in Table 4 below.

Among the aspects which were assessed in the students' essay writing, organization followed by focus and detail, and voice were the aspects which were mostly developed. However, word choice or vocabulary seems to have the least increase among the other aspects. The following table showed the means score distribution of the aspects of the students' essay writing.

\section{DISCUSSION}

Based on the results of the pretest and post test of the students' essay writing achievement, it can be seen that there is an increase in students' achievement in writing an essay between before and after they got the treatment by using reading and writing connection strategy. The average essay writing achievement increased from 63.6 to 79.8. In other words, students' writing skills improved from fair category to good category. The $\mathrm{t}$-test results also showed that the $\mathrm{t}$ value is smaller than 0.05 . In other words, there is a significant

Table 3. The result of paired-Sample t-test of students essay writing in pretest and post test

\begin{tabular}{|c|c|c|c|c|c|c|c|c|}
\hline & \multicolumn{5}{|c|}{ Paired differences } & \multirow[t]{3}{*}{$\mathbf{T}$} & \multirow[t]{3}{*}{ df } & \multirow[t]{3}{*}{ Sig. (2-tailed) } \\
\hline & \multirow[t]{2}{*}{ Mean } & \multirow[t]{2}{*}{$\begin{array}{l}\text { Standard } \\
\text { deviation }\end{array}$} & \multirow[t]{2}{*}{$\begin{array}{c}\text { Standard } \\
\text { error mean }\end{array}$} & \multicolumn{2}{|c|}{$\begin{array}{l}\text { 95\% Confidence } \\
\text { interval of the } \\
\text { difference }\end{array}$} & & & \\
\hline & & & & Lower & Upper & & & \\
\hline \multicolumn{9}{|l|}{ Pair 1} \\
\hline Pretest - posttest & $-1.65000 \mathrm{E} 1$ & 8.96660 & 2.24165 & -21.27797 & -11.72203 & -7.361 & 15 & 0.000 \\
\hline
\end{tabular}

Table 4. The results of pretest and posttest results of the aspects of the students' writing

\begin{tabular}{lccc}
\hline Aspects of essay writing & Pretest & Posttest & Improvement \\
\hline Focus and detail & 2.1 & 3.7 & 1.6 \\
Organization & 1.1 & 3.7 & 2.6 \\
Voice & 2 & 3.6 & 1.6 \\
Word choice & 3 & 3.2 & 0.2 \\
Sentence structure, grammar, mechanics \& spelling & 2 & 3 & 1 \\
\hline
\end{tabular}


difference in essay writing achievement between before and after the students were taught through reading and writing connections strategy. The improvement in the students' essay writing ability might happen because the students involved in intensive activities in reading and writing connection activities. The reading activities provide the students opportunities to identify the structure of an essay as well as understand on how the author develop the ideas of an essay. Therefore, they might find it easier when they have to write their own essay as they have got some prior knowledge on how to develop a topic into an essay. This is inline with Tompkins (2008) who states that reading and writing activities are important because at the time of reading, the reader will learn how the author uses certain structures and understand the impact. The steps in the reading and writing connections strategy really help the students to develop their writing as they understand that in order to write an essay they need to develop the topic based on certain logical patterns of ideas for an essay.

The results of the students' writing achievement also showed an improvement in the aspects of writing. Among the five asepcts of writing, organization followed by focus and detail as well as voice seemed to be the aspects which increase a lot. This implies that by reading some examples of the writing, the students can find the patterns and see how the writers develop the topic based on those logical patterns of ideas. Oshima and Hogue (1999) divided the organization of ideas into three kinds: chronological order, logical division of ideas or order of importance, and comparison and contrast. Each types of writing has its own logical pattern of ideas which is different from one to the other. Therefore, students need to be exposed with those differences as to help them to write in the appropriate pattern of organization of ideas. In conclusion, reading and writing strategies help the students to improve their ability in writing an essay.

Despite of those improvement in most of the writing aspects, students seem still have difficulties in improving their word choice or vocabulary aspect of their writing. This might be due to the students' limited vocabulary mastery. They were not successful enough in integrating the vocabulary the got from the text they read prior to the writing activities into their own writing. Therefore, students also need to be encouraged to use more varied vocabulary in their writing.

\section{CONCLUSIONS}

Based on the findings and the statistical analysis, it was found that there was a significant difference in writing achievement of the fifth semester students of English Education Study Program between before and after the students were taught by using reading and writing connections strategy. Therefore, it can be concluded that the teaching of essay writing by using the reading and writing connection strategy helped students of English Education Study Program of FKIP Unsri to improve their ability in writing an essay. Thus, this strategy can be used as an alternative for the teaching of essay writing. However, effort still need to be done as students still did not make a lot of progress in the aspect of word choice or vocabulary.

\section{REFERENCES}

Bromley, K.D.A. (1989). Buddy Journals Make the Reading-Writing Connection. The Reading Teacher, 43(2), pp. 122-129 www.jstor.org.

Corden, R. (2007). Developing Reading-writing connections: The Impact of Explicit Instruction of Literacy Devices on the Quality of Children's Narrative Writing. Journal of Reseach in Childhood Education, 21(3).

International Reading Association. (2013). Essay rubric. Retrieved May 16, 2017 from nwid.ndia.org

Oshima, A \& Hogue, A. (1999). Writing Academic English. White Plains, NY: Addison Wesley Longman.

Shen, M.Y. (2009). Reading-writing connections for EFL College Learners' Literacy Development. Asian EFL Journal, 11(1), pp. 89-108.

Shim, J. (2004). Exploring reading and writing connections: A structural equation modeling approach. English Teaching, 59(2), pp. 59-74.

Language and online learning. Sampel Essay. (2017). Retrieved May 16, 2017, from Monash University website http://www.monash.edu.au/lls/llonline/writing/general/ essay/sample-essay/index.xml

Tompkins, G.E. (2008). Teaching Writing: Balancing Process and Product. Upper Saddle, River, NJ: Pearson Education. 